\title{
Los Célticos de Gallaecia: apuntes sobre etnicidad y territorialidad en la Edad del Hierro del Noroeste de la Península Ibérica
}

\section{The Celtici from Gallaecia: notes on ethnicity and territoriality in the NW Iberian Peninsula during the Iron Age}

\author{
Francisco Javier GonzÁlez GARCíA \\ Universidad de Santiago de Compostela \\ franciscojavier.gonzalez@usc.es
}

Recibido: 17-08-2010

Aceptado: 14-12-2010

\section{RESUMEN}

En la primera parte del presente artículo se revisan y critican dos tópicos de la investigación protohistórica sobre la Edad del Hierro del NO de la Península Ibérica: la negación del carácter céltico de algunos de sus pueblos y el rechazo a las noticias que nos ofrecen las fuentes literarias clásicas. La segunda parte se centra en mostrar la existencia de una serie de indicios materiales que pueden ayudar a delimitar, dentro del registro arqueológico del NO Peninsular, áreas territoriales internas o a definir distintas etnicidades.

Palabras Clave: NO de la Península Ibérica. Edad del Hierro. Etnicidad. Celtas.

\begin{abstract}
This paper discusses in the first place two stereotypes of the research on the Iron Age of NW Iberian Peninsula: the refusal of Celtic ethnicity for some pre-roman peoples and the rejection of the historical evidence available from Greek and Roman texts. Secondly, this paper tries to show that some material evidence may be used to delimit inner areas within the archaeological record of NW Iberian Peninsula as well as to define different ethnicities.
\end{abstract}

Key Words: NW Iberian Peninsula. Iron Age. Ethnicity. Celts.

SUMARIO 1. Introducción. 2. ¿Celtas o "celtoides"?: sobre la caracterización cultural y lingüística de los pueblos galaicos del litoral. 3. Criterios para la determinación de la territorialidad interna en la Edad del Hierro del NO: entrecruzando datos literarios, epigráficos y arqueológicos. 


\section{1.- Introducción 1}

Desde la década de los 80 del pasado siglo hasta la actualidad, la investigación protohistórica gallega sobre la Edad del Hierro se ha venido caracterizando por su rechazo, a la hora de explicar las poblaciones de esta área, a cualquier tipo de referencia étnica o sustrato cultural, en concreto céltico, y por la potenciación del dato arqueológico cómo único material documental válido (González García 2007: 72 ss. y 100 ss.). Esta segunda característica llevaba implícito, además, el rechazo de la validez de las informaciones que nos ofrecen otras fuentes documentales, en especial la literatura clásica; rechazo que derivaba de la crítica a que fueron sometidos, a finales de la década de $\operatorname{los} 70 \mathrm{y}$ durante los años 80 , los textos clásicos que nos informan sobre la protohistoria del NO peninsular (Alonso del Real 1977-1978; Bermejo 1982 y 1986). Crítica que provocó que se llegase a afirmar que determinadas noticias o descripciones que ofrecen dichas fuentes, como es el caso, por ejemplo, de algunas de las aportadas por Estrabón, "han quedado desacreditadas en la investigación desde hace tiempo" (Pereira Menaut 1992a: 320, nota 14), considerando que manipulaban la realidad histórica en beneficio del poder romano y que estaban llenas de tópicos.

Esta situación no sólo no ha cambiado mucho en los últimos años sino que, además, se ha asistido a la aparición de dos nuevos fenómenos que parecen indicar que, entre determinados sectores de la investigación, no se va a producir ninguna variación en este sentido. Me refiero a la asunción de estos puntos de vista por parte de los sectores más jóvenes de la investigación y a la manifestación, en aquellos investigadores de más edad, de cierto inmovilismo, del rechazo a aceptar cualquier punto de vista que pueda variar sus argumentaciones.

Una reciente síntesis sobre la Edad del Hierro en el NO, cuyo autor es un joven investigador (Rodríguez Corral 2009), nos ofrece un perfecto ejemplo de la primera de dichas situaciones. Dicha

\footnotetext{
${ }^{1}$ Las figuras del presente trabajo han sido realizadas por Anxo Rodríguez Paz a partir de las referencias señaladas como fuentes en cada uno de los pies de imagen. Los límites que aparecen reflejados en los mapas son, con excepción del número 3 , meramente orientativos.
}

obra, tanto por su título, con mención explícita al término "castrexo", como por la ausencia, en su texto, a cualquier tipo de referencia a la etnicidad o al sustrato cultural céltico que se pueda encontrar bajo aquella, se encuadra a la perfección, pese a cierto aggiornamento teórico debido, quizás, al influjo de otros jóvenes autores (González Ruibal 2006-2007), dentro de la tradición investigadora, antes mencionada, de la protohistoria galaica.

Por lo que respecta al inmovilismo, se trata de una postura ya anunciada hace unos años a través de la publicación de la síntesis divulgativa de A. de la Peña (Peña 2003), en la que, para lo relativo a la Edad del Hierro, se repetía la misma explicación ofrecida, once años antes, en el monográfico de Complutum dedicado a la Paleoetnología de la Península Ibérica. La consideración de esta postura como muestra de una tendencia se ha visto confirmada, posteriormente, con la publicación de dos trabajos firmados, respectivamente, por Bermejo Barrera (2008) y Calo Lourido (2010).

La primera de dichas obras (Bermejo 2008) es la reedición, en traducción al gallego, con nuevo título y sin grandes cambios en su redacción, salvo el añadido de algunos capítulos previamente publicados como artículos de revista, de una de las obras más novedosas, en el momento de su publicación (1978), de la investigación sobre protohistoria gallega: La sociedad en la Galicia castreña. Esta práctica ausencia de cambios en la redacción del texto implica una validación, en la actualidad, de los contenidos de la obra original, publicada hace más de 30 años. Creo que, por este motivo, dicho trabajo ofrece un magnífico ejemplo de esta postura inmovilista que, como ha indicado García Quintela (2009), llega a alcanzar el carácter de una auténtica "historia del tiempo abolido" en la que el autor se niega, ignoramos los motivos, a reconocer los logros de las investigaciones desarrolladas dentro de este campo en las últimas tres décadas; logros entre los cuales merece la pena destacar, por ejemplo, la rehabilitación, durante los últimos diez o quince años, de Estrabón como autor y de su obra como fuente documental (Clarke 1999; Dueck 2000; Dueck, Lindsay y Pothecary 2005 o, en la investigación hispana, Gómez Espelosín, Cruz Andreotti y García Quintela 2007).

La monografía de Calo Lourido (2010) ofrece otro buen ejemplo de este planteamiento inmovilista, tal y como lo demuestra el hecho de que, 
básicamente, todo el libro se constituye como una defensa de las posturas celto-escépticas del autor, ya expuestas en trabajos anteriores (como su popular Cultura Castrexa de 1993), a través de una revisión del problema del celtismo en Europa, España y Galicia.

El presente artículo tiene como objetivo criticar, una vez más, estas características de la investigación protohistórica gallega y, para ello, nos centraremos, en un primer momento, en la crítica al rechazo al celtismo, a través de la exposición de uno de los tópicos más difundidos por algunos sectores de la investigación protohistórica y que, recientemente, ha sido retomado por Calo (2010: 139-156): la negación del carácter céltico de algunas poblaciones galaicas de la Edad del Hierro, fundamentalmente los pueblos prerromanos del litoral, tal y como nos los describen las fuentes clásicas. El recurso a las noticias de los autores antiguos y su entrecruzamiento con otro tipo de datos también nos servirán para criticar el rechazo de muchos investigadores hacia las noticias que nos ofrecen las fuentes literarias clásicas; nuestra finalidad, a este respecto, consiste en re-acreditar a los autores griegos y latinos como testimonios históricos fidedignos una vez sometidos, como cualquier otra fuente histórica o arqueológica, al correspondiente proceso crítico.

En la segunda parte de nuestro trabajo nos centraremos, sobre todo, en el dato arqueológico, tan sobrevalorado en la investigación gallega, con la finalidad de intentar demostrar que otras lecturas del mismo son posibles y que, incluso, pueden contribuir a la definición de etnicidades protohistóricas. En estas páginas señalaremos, a modo de hoja de ruta de futuras investigaciones, una serie de indicios arqueológicos y epigráficos que, combinados con las noticias de las fuentes antiguas, pueden ayudar, en primer lugar, a establecer la posible "celticidad", desde el punto de vista de la cultura material, de las poblaciones prerromanas del NO ibérico. La fijación de estos criterios de diferenciación, desde el punto de vista de la cultura material, de poblaciones célticas y no célticas en el NO, ofrece además una segunda perspectiva futura de investigación protohistórica, en la medida que fija una serie de indicios básicos que pueden ser de gran utilidad para el establecimiento de criterios internos de territorialidad dentro del mundo prerromano del Noroeste.

\section{2. ¿Celtas o "celtoides"?: sobre la caracteriza- ción cultural y lingüística de los pueblos galai- cos del litoral}

Los autores antiguos, en sus descripciones de la costa galaica, nos informan de la presencia de una serie de poblaciones a las que denominan como keltikoí o celtici, es decir, célticos, y a las que sitúan en la costa atlántica ibérica desde el curso del río Duero hasta la costa Norte peninsular, una vez superado el cabo Nerio o Céltico, punto de inflexión entre la costa occidental y septentrional de la Península Ibérica (Estrabón, Geografía, III, 3, 5; Pomponio Mela, Corografia, III, 9-13; Plinio, Historia Natural: III, 28 y IV, 111).

Un sector importante de la investigación gallega e hispana sobre la Edad del Hierro en el NO rechaza la presencia de componentes célticos en la protohistoria gallega (Calo 1993: 60-65; Peña 2003: 119-126 y Sastre 2001: 78-93), planteamiento que, curiosamente, no es compartido por algunos sectores de la investigación arqueológica portuguesa (por ejemplo: Alarcâo 1992). No vamos a entrar aquí en detalles sobre la historiografía del celtismo en la investigación gallega, su génesis y su crítica, ni tampoco en una exposición pormenorizada de los diferentes posicionamientos sobre el tema del celtismo en Galicia, temas para los que remito a un reciente trabajo (González García 2007). Simplemente indicaré que este comportamiento resulta totalmente lógico si se comprende como un movimiento de rechazo a la interpretación marcadamente celtista de la protohistoria gallega que se desarrolló en el siglo XIX con la obra de autores como Murguía y que tuvo su continuidad, en la primera mitad del XX, en los trabajos de la Xeneración Nós, hipótesis que, básicamente, fueron las que manejó la investigación protohistórica gallega, hasta el último tercio del siglo XX, para explicar la Edad del Hierro.

El argumento fundamental para rechazar, en la actualidad, la presencia de celtas en Galicia es básicamente arqueológico: la eclosión céltica coincide con la cultura de La Tène. Si tenemos en cuenta la ausencia de "latenización" del registro arqueológico de la Edad del Hierro del NO peninsular podemos concluir, como hacen algunos autores, que en estas áreas no hubo presencia céltica (Calo 1993: 62). Esta limitación del fenómeno de lo céltico a lo estrictamente arqueológico es reduc- 
cionista y errónea, pues deja a un lado otro tipo de indicios, como los lingüísticos, de gran utilidad para intentar dar una solución al problema de la presencia céltica en el NO peninsular.

Esta negación del componente cultural celta del NO desde el punto de vista de la arqueología nos obliga, por tanto, a recurrir a otro tipo de documentación. Veamos, así pues, qué nos dice el material lingüístico. Blanca Prósper (2002: 25-26) ha afirmado recientemente que, en el NO peninsular, tanto las noticias de los autores antiguos como la toponimia antigua y moderna documentan, sin duda, la presencia de lenguas célticas y, en concreto, la existencia de un posible dialecto "hispano celta-occidental", con características distintas a las del celtibérico. Dialecto que, para otros autores, como Bernardo Stempel (2002: 97 ss.), quien lo denomina celta hispano y considera que no sólo se hablaría en el sector occidental de la Península sino en toda la periferia septentrional y occidental de la misma, sería mucho más antiguo que el celtibérico y del cual este último habría evolucionado.

Por poner un ejemplo tomado de la toponimia, los análisis de García Alonso (2003: 449-453) y Luján (2000: 66) sitúan entre un 55\% y un 30\% los topónimos de origen céltico que, en su obra, recoge Ptolomeo cuando se refiere al NO peninsular. Estos porcentajes, pese las diferencias registradas entre ambos autores, nos hablan, evidentemente, sobre una destacada presencia céltica en dichas regiones. A favor de esta importante celtización del NO podríamos citar otros indicios, como, por ejemplo, los frecuentes topónimos en -briga o -bris / -bri (Albertos 1990: 133; García Alonso 2006) que se atestiguan en dicha área y, sobre todo, la abundantísima toponimia actual en -bre que, desde los trabajos de Moralejo Lasso, se sabe que deriva de las formas antiguas en -bris, -bri, emparentadas con la forma céltica en -briga (Villar 2000: 33; Untermann 1993: 378 y n. 42).

Esta presencia de componentes lingüísticos célticos en Galicia, junto con restos e indicios de otras lenguas anteriores, como el lusitano, es un hecho aceptado en la actualidad por la investigación en lingüística comparada indoeuropea (ver, por ejemplo, Gorrochategui 1993 y 1997; Hoz, 1993 y 1997; Moralejo 2008: 25-52; Villar 1996, 485 ss.; Villar 2001: 119).

Algunos sectores de la investigación arqueológica e histórica defienden dos posibles hipótesis explicativas de la presencia de esta toponimia cél- tica: su introducción en el NO gracias a la entrada de elementos célticos llegados como tropas auxiliares en época de Augusto (Calo 1993: 63, siguiendo un argumento apuntado por Jordá Cerdá 1984: 8-9 y recientemente retomado en Calo 2010: 150-151) o que se trató de una introducción paulatina de elementos de población y topónimos desde territorio celtibérico, con anterioridad a la conquista y al compás del desarrollo social del mundo local de la Edad del Hierro, que se habría intensificado a partir de la conquista e integración de esta área dentro de la órbita del Imperio romano (Peña 2003: 180; una crítica a estos argumentos en Brañas 2000: 29-34).

A juzgar por los datos que nos ofrecen los autores antiguos, cuyas noticias se datan entre fines del siglo I a.C. y el siglo I d.C., sobre la extensión de estos pueblos célticos del litoral, aceptar que esta presencia de celtas se deba a las tropas auxiliares de Augusto no parece una hipótesis muy afortunada ni desde el punto de vista histórico, si tenemos en cuenta la tímida ocupación militar que esta área parece haber conocido durante la etapa julio-claudia (González García 2008: 47-49), ni desde un planteamiento lingüístico, tal y como lo demuestra la siguiente afirmación de Moralejo (2008: 37): "me parece una frivolidad estéril atribuir toda o buena parte del material indoeuropeo prelatino, céltico o no, a la presencia de auxiliares, mercenarios o como se les quiera llamar, que se asientan en el territorio en cuya conquista han ayudado a los romanos". Por su parte, la segunda hipótesis, que responsabiliza de la celtización a la entrada de elementos celtibéricos, se viene abajo si las conclusiones de los lingüistas, como las ya mencionadas de Prósper o de Bernardo, son correctas y la lengua celta que se hablaba en el NO es distinta a la de Celtiberia.

La noticia de Estrabón (III, 3, 5) que menciona la llegada de poblaciones célticas procedentes del $\mathrm{SO}$ de la Península a las tierras situadas al $\mathrm{N}$ del Duero podría sugerir una posible vía de entrada, en el NO, de componentes célticos; de tal modo que, según las noticias del geógrafo de Amasia, los keltikoí del NO estarían emparentados con los célticos del sur del Anas (Berrocal Rangel 1992, 34; Untermann 1993, 385). El análisis de esta última posibilidad implica, para su corroboración, la realización de un estudio del posible momento en que se produjo la llegada de dichas poblaciones al NO y un análisis comparativo de las culturas materiales y los datos lingüísticos de ambas zonas de la 
Península Ibérica, cuestiones ambas que rebasan, con mucho, los objetivos que aquí nos hemos propuesto.

La revisión de los datos lingüísticos parece confirmar que el argumento de peso para rechazar la presencia de elementos culturales célticos en el NO prerromano es fundamentalmente arqueológico. Esta negación no sería importante si, con ella, no se estuviese negando otro tipo de material documental, en este caso una fuente primaria: el conjunto de epígrafes latinos sobre los célticos supertamar(i)cos que nos permite confirmar la veracidad de la noticia que nos ofrece Plinio (IV, 111) sobre uno de los pueblos indígenas del litoral.

Este conjunto epigráfico está compuesto por cinco estelas funerarias. Se trata de documentos típicos de contextos privados y caracterizados por hacer referencia a individuos que, a juzgar por sus nombres, su sistema de filiación y la forma de establecer su origen o procedencia, parecen haber estado poco romanizados. Todas las piezas de este conjunto recogen los epitafios de varios celticos, "celtas", supertamaricos (o celtas que habitaban los territorios al $\mathrm{N}$ del Tambre) en los que, por haber fallecido lejos de su lugar de origen, se menciona su procedencia (textos de los epígrafes y comentarios en García Martínez 1999, 413-420; Rodríguez Colmenero 1999, 608; Albertos 1974-1975, 313-318).

Todo parece indicar que, en el caso de este etnónimo, no estamos ante una denominación impuesta por el poder romano (afirmación compartida, para el conjunto de los pueblos de la Edad del Hierro del NO, por otros autores, como Alarcâo 2009: 91), sino que se trata de la designación étnica que se daba este grupo indígena; étnico que, a diferencia de lo que se había venido pensando, en realidad puede ser, tal y como apuntó Untermann (1993: 385-386 y 2004: 200), la helenización o la latinización de un etnónimo indígena (*keltikos) derivado de la raíz kelt- y no una creación griega o romana.

Las noticias de Estrabón, Mela y Plinio sobre la existencia de poblaciones célticas en ese sector de la costa peninsular no se pueden obviar pero sí se puede argumentar sobre ellas con la intención de desacreditar a sus autores como informantes. En este sentido se ha orientado la interpretación de J. de Hoz (1997: 107-108; seguido por Pereira Menaut 1998: 320; Peña 2003: 120; Luján 2006: 716; Calo 2010: 144) quien considera que con esta denominación se hace referencia a "celtoides", es decir, a pueblos que se parecen a los celtas pero que, realmente, no lo son. Esta explicación es, curiosamente, una de las tres hipótesis que este mismo autor barajaba en un trabajo anterior (Hoz 1993: 359) para explicar que el término celticus como étnico apelativo sólo apareciese, en los autores latinos, referido a poblaciones de la Península Ibérica. Dichas hipótesis eran: a) que con dicha denominación se estuviese aludiendo a una subnación céltica específica, distinta de la celtíbera; b) que se tratase de distintas naciones que se reconocían como celtas o c) que estuviésemos ante pueblos que, sin ser celtas, habrían asumido rasgos célticos, es decir, habrían sido celtizados. Ignoro los motivos que pudieron llevar a de Hoz a abandonar las otras dos hipótesis, cuestión carente de importancia para el tema que aquí nos ocupa, dado que nuestro interés se centra en saber si dicha explicación es correcta, para lo cual lo mejor es, sin duda, recurrir a los autores antiguos y ver el uso que han hecho del término celticus.

En toda la literatura latina recogida en la colección Teubner (BTL-1, 1999), se constata la aparición del término celticus en un total de 31 ocasiones. De ellas, 11 son los pasajes en que se hace referencia al NO de la Península, las restantes menciones tienen que ver con su uso como adjetivo o sustantivo en diferentes contextos: 3 referencias a una planta, nardum celticum, la valeriana celtica, 1 a las viria o brazaletes célticos, 4 a poblaciones hispanas y 12 a poblaciones europeas. El testimonio más importante para nuestro argumento procede de una cita de Tito Livio $(\mathrm{V}, 34,1)$ que caracteriza como "celtici" a los Biturigos y a su jefe, Ambigatus, personaje y pueblo cuya celticidad no ofrece dudas (Der Neue Pauly 1997, Bd.2, I, 704-705):

Parece, por tanto, que "celticus" no se puede interpretar como "celtoide" y que cuando un autor latino designa a los pueblos del litoral costero como célticos, realmente está hablando de pueblos que, para él, eran celtas. Esta conclusión parece reforzada por el hecho de que, según el Oxford Latin Dictionary, el adjetivo celticus, $-a$, - um y el sustantivo neutro celticum, con el que se designa a la raza celta, eran los términos con que contaba el latín para designar en singular a un individuo de dicho origen, pues celta es una palabra que, en dicha lengua, sólo existe en plural: celtae,-arum.

$\mathrm{Si}$ de las denominaciones dadas por los romanos pasamos a la que nos ofrece Estrabón (keltikoi) 
vemos, comparando esta denominación con otras referidas a otras poblaciones célticas mencionadas por dicho autor en otros libros de su obra (VI.4.2; VII.1.1-3; VII.1.5; VII.3.2; VII.5.1-2; VII.5.4; XII.5.1), que nos encontramos en una situación similar: se trata de auténticas poblaciones celtas; afirmación confirmada, en este caso, por el Greek English Lexikon de Oxford, según el cual keltikós, $-e$, ón es un adjetivo derivado del sustantivo plural keltoí, que posteriormente, en época más tardía, adoptó también la forma keltaí, es decir: celtas.

Otra cuestión distinta es que aquellos individuos o poblaciones que para un autor latino o griego eran celtas sean lo mismo que para nosotros (es decir, y tal y como parece suceder en el caso de la mayoría de los arqueólogos gallegos, que se trate de pueblos caracterizados por una cultura material de tipo laténico). Todo parece indicar, por tanto, que podemos aceptar el carácter céltico de la lengua y cultura de estos pueblos, del mismo modo que aceptamos los de otras poblaciones europeas y peninsulares a partir de las descripciones que de ellas nos ofrecen los autores antiguos.

La principal confirmación de la utilidad de las noticias de los autores antiguos en lo que respecta a la definición de algunos populi del NO peninsular como poblaciones de cultura céltica deriva, sin embargo, del entrecruzamiento de sus datos con otros de distinto origen como los lingüísticos. Como ya hemos mencionado, tanto Estrabón, como Mela y Plinio sitúan a las poblaciones de origen céltico del NO en el área geográfica que abarca desde la desembocadura del Duero hasta el arranque de la costa $\mathrm{N}$ de la Península. En esta zona, y dentro del actual territorio de la provincia de A Coruña, se concentraban una serie de pueblos como los ártabros, los nerios, supertamar(i)cos y prestamarcos, todos ellos calificados como célticos por los autores antiguos, que se pueden ubicar entre el curso del río Ulla y la ría de O Ferrol (Fig. 1). Esta misma área (Fig. 2) es la zona de mayor concentración de topónimos actuales en -bre que,

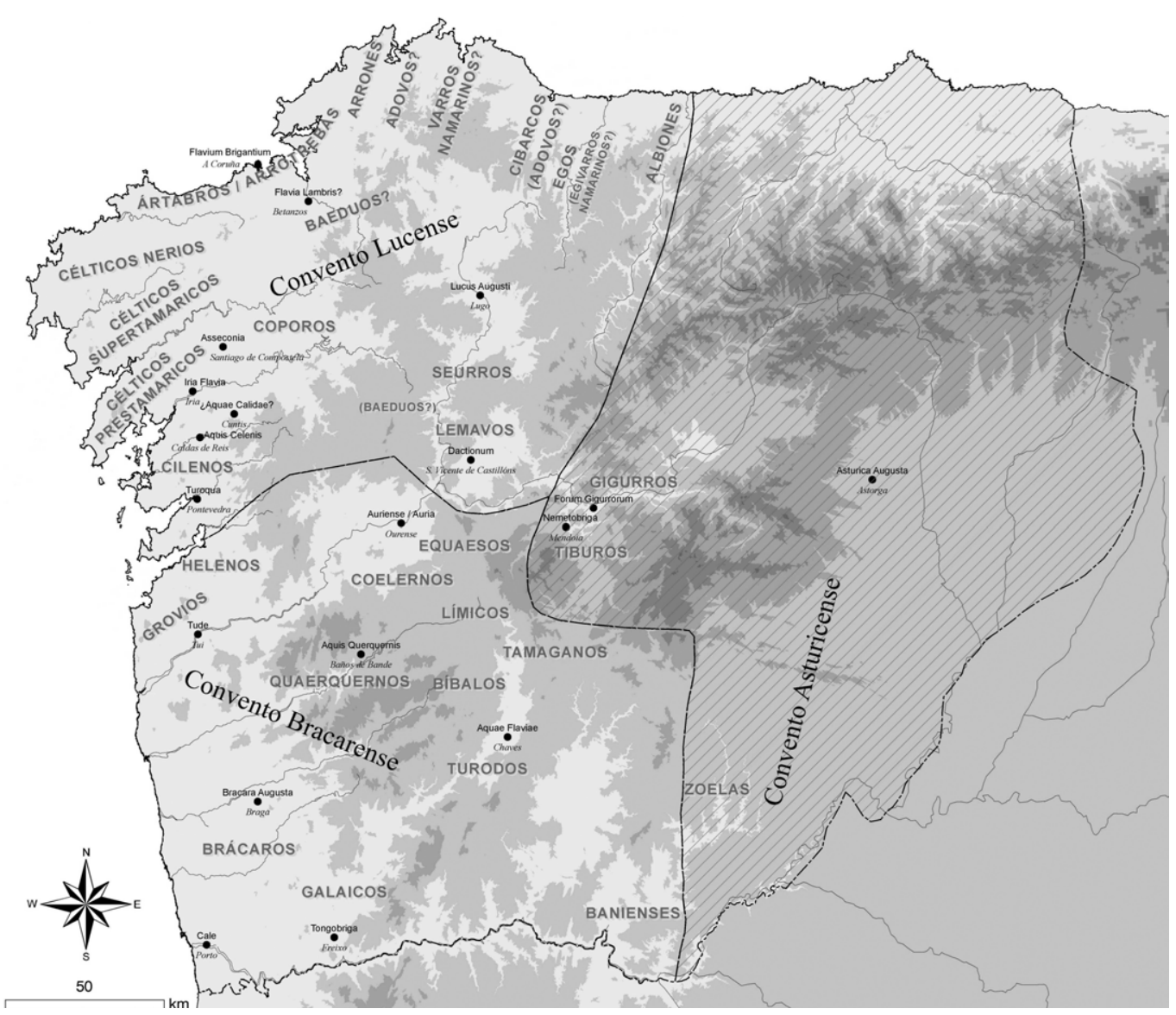

Figura 1.- Populi del NO de la Península Ibérica (Fuente: González García 2007: 544).

Complutum, 2011, Vol. 22 (1): 117-132 
como ya adelantamos, derivan, en su mayor parte, de antiguas formas toponímicas célticas terminadas en -bris o en -bri (Búa Carballo, Lois Silva 1994-1995: 26; Búa Carballo 2004; con respecto a aquellos que no derivan de dicha raíz: Moralejo 2008: 171-195). Vemos, así pues, cómo los autores clásicos y la lingüística coinciden a la hora de señalar la importante presencia y ocupación céltica en un área concreta de la actual Galicia; coincidencia que todavía aumenta más si tenemos en cuenta que, tal y como se puede apreciar en el mapa 2, la mayor concentración de topónimos en -bre, de implantación céltica, por tanto, coincide con las áreas de las rías de A Coruña, Betanzos y O Ferrol, al actual Golfo Ártabro, área en la que, según Estrabón (III, 3, 5) existían, en la antigüedad, "numerosas ciudades agrupadas en el golfo que los navegantes que tienen relación con estos lugares denominan Puerto de los Ártabros".

La huella dejada en esta área por la presencia céltica también nos la confirman ciertos datos que arrancando desde época altomedieval llegan hasta nuestros días: la existencia de una subdivisión eclesiástica de la diócesis de Santiago, el actual archiprestazgo de Céltigos que, con una superficie de $270 \mathrm{~km}^{2}$, abarca parroquias pertenecientes a los ayuntamientos de A Baña, Mazaricos, Negreira, Santa Comba y Zas (Fig. 3; Torres Luna, Pazo Labrador 1994: 333 y 362). Dicho arciprestazgo, creado, al igual que todos los demás de la diócesis compostelana, en torno al año 1100, heredó su denominación de una antigua parroquia altomedieval de la sede de Iria, mencionada, ya, en el Parrochiale suevum (XI.8), texto en el que se recoge la división diocesana de la Galicia del siglo VI (López Alsina 1988: 156, 166 y 174; Novo Güisán 1997-1998: 183) y cuya extensión, como sabemos, se vio alterada entre dicha época y el año 1050 (López Alsina 1988: 156-157 y 164-166: mapas 1, 3,4 y 5). El carácter antiguo de la división en parroquias que, para la sede de iriense, nos ofrece el Parrochiale, vendría dado, como ya ha sido indicado con frecuencia, por sus denominaciones, basadas, todas ellas, en étnicos prerromanos (López Alsina 1988: 156; Novo Güisán 19971998: 183).

Esta concentración de población céltica en la Antigüedad en el sector que va desde el río Ulla hasta la ría de O Ferrol no implica, evidentemente, que dicho sector concentrase, en esta época, a todas las poblaciones de lengua y cultura céltica de

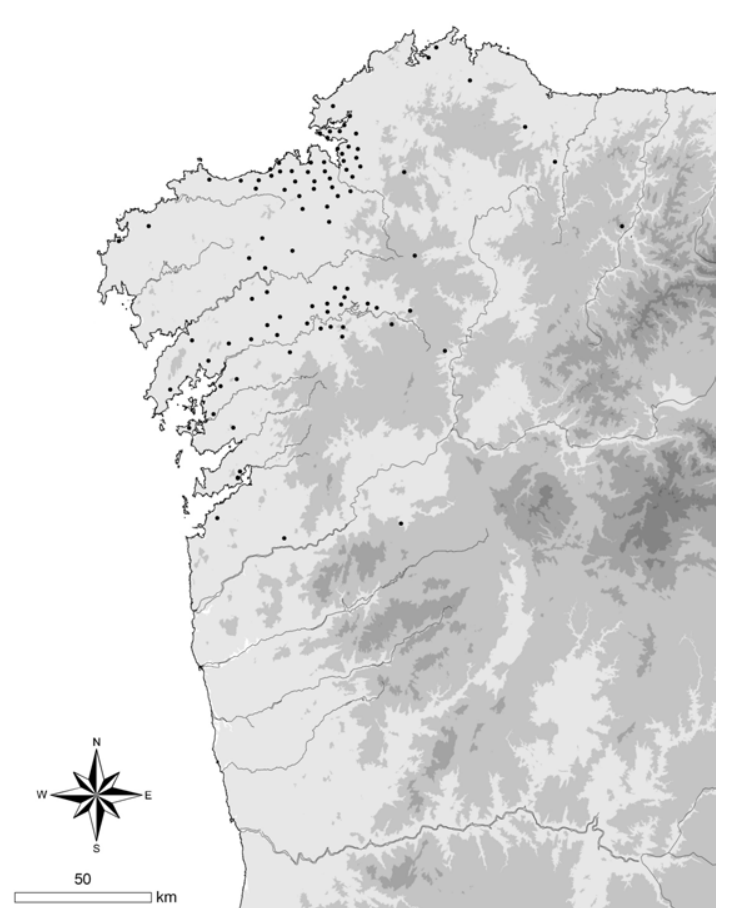

Figura 2.- Distribución de los topónimos gallegos de origen prerromano en -bre (Fuente: Búa Carballo, Lois Silva 1994-1995: 26).

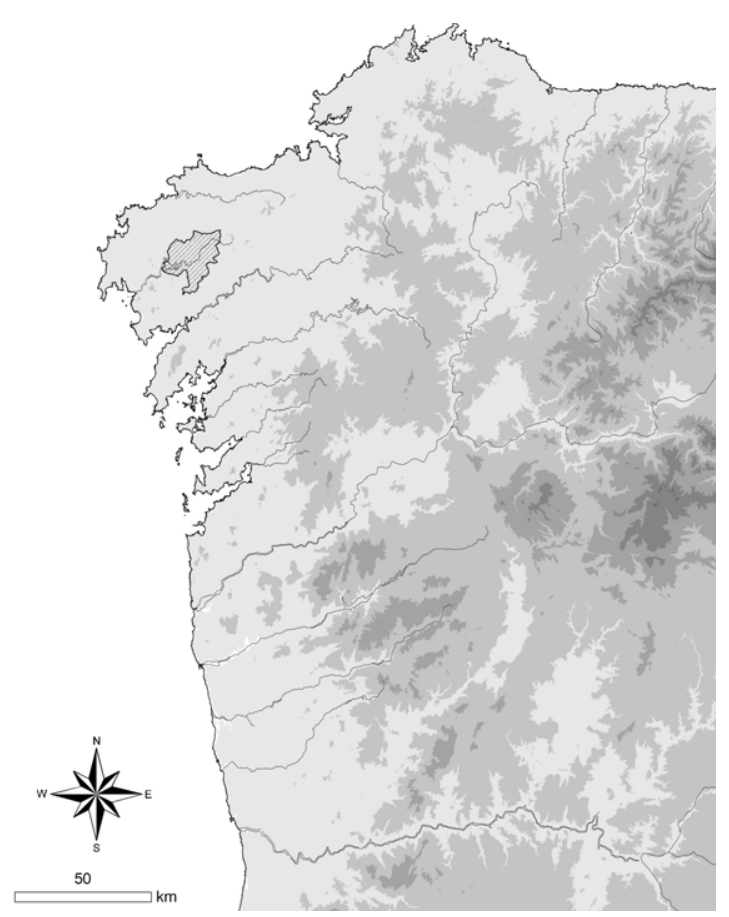

Figura 3.- Extensión actual del arciprestazgo de Céltigos (Fuente: Torres Luna,, Pazo Labrador 1994: mapa de arciprestazgos de Galicia). 
estas regiones. La ventaja que presenta esta área para aclarar el valor de las noticias de las fuentes y la presencia de poblaciones célticas en el territorio de la actual Galicia viene dada por el hecho, excepcional, de que se trata de una zona para la que hay suficientes noticias en las fuentes literarias antiguas y en la que se ha realizado un buen análisis de un tipo de topónimo de origen claramente céltico, aquellos finalizados en -bre. Este tipo de topónimo no es el único de origen céltico que se conserva en Galicia, existen muchos más, al igual que otros muchos etnónimos célticos entre las restantes poblaciones del NO mencionadas por los autores antiguos y por las fuentes epigráficas. El estudio entrecruzado de unos datos y otros daría, a buen seguro, resultados similares a los que hemos visto aquí.

A juzgar por todos estos datos, la descripción de los pueblos del litoral atlántico peninsular a partir del curso del Duero que nos ofrecen los autores antiguos se nos presenta, por tanto, como una fuente de información fiable, tanto en lo que respecta a la localización de dichos pueblos como en lo relativo a su adscripción cultural. Antes de cerrar esta primera parte del trabajo y para reafirmar esta defensa del papel de las fuentes clásicas como testimonios históricos fidedignos, me gustaría ofrecer un par de ejemplos más que apuntan en dicha dirección. En la actualidad, varias noticias puntuales de Estrabón, el más denostado de todos los autores clásicos que hablan sobre el NO peninsular, se han visto confirmadas, con el paso del tiempo, como consecuencia de la actividad arqueológica. Destacamos, por ejemplo, la existencia de viviendas con banco corrido pegado a la pared que se utilizaban en determinadas celebraciones (Estrabón III, 3, 7); construcciones que las excavaciones arqueológicas han sacado a la luz y que por su tamaño, superior al de resto de las construcciones de los asentamientos en que aparecen, se interpretan como "salas de reunión" (por ejemplo, la famosa casa con banco corrido de la citania de Briteiros, Guimarâes, Portugal, así como otras documentadas en el NO peninsular: Ayán 2008: 939 y 950); incluso podemos referirnos a otras noticias mucho más concretas como la existencia de unos Turduli procedentes de la zona del Anas (actual Guadiana) que se asentaron en el NO peninsular (Estrabón III, 3, 5) y cuya presencia en esta zona, en concreto entre los cursos del Vouga y Douro, se ha visto confirmada gracias a la aparición de dos tabulae hospitalis en el castro de
Monte Murado, en la feligresía de Pedroso, Vila Nova de Gaia, Portugal (Silva 1983; Balbín Chamorro 2006: 193-195; Silva 2007: 391-392).

\section{Criterios para la determinación de la territo- rialidad interna en la Edad del Hierro del NO: entrecruzando datos literarios, epigráficos $y$ arqueológicos}

Uno de los argumentos tradicionalmente esgrimidos a la hora de negar o minimizar el peso del componente céltico en la cultura de la Edad del Hierro del NO ha sido la gran homogeneidad que ésta presenta a lo largo de toda su área de extensión. Este hecho parecía negar la posible existencia de diferencias indicativas de distintas características étnicas o lingüísticas tanto entre áreas como en el interior de una misma zona dentro del conjunto cultural de la Edad del Hierro de dicha región. Algunos autores, como Calo (1993: 62), han defendido la primacía de la arqueología y de la homogeneidad de la cultura material sobre cualquier otro tipo de indicio, afirmando que no aceptan que se diga que un castro es celta aunque en él se hubiese hablado una lengua celta. Esta afirmación nos sirve para confirmar ese inmovilismo al que nos referíamos al inicio, pues a día de hoy, diecisiete años después de la publicación del trabajo en que fue realizada, Calo sigue negando la posibilidad de llegar a distinguir rasgos étnicos o diferencias internas en el registro de Edad del Hierro del NO: "Escavei no castro do Neixón e dirixín as escavacións do de Baroña, ambos os dous en territorio dos praestamarci, e podo asegurar que nada vin que indicase que alí viviron unhas xentes diferentes ás do resto da zona centro occidental do convento xurídico lucense. Se alí houbo célticos, nin pola arquitectura nin pola ergoloxía se detectan" (Calo 2010: 155).

Estas afirmaciones resultan, a mi entender, excesivas y ello por dos razones. Primero, porque el problema de las etnicidades antiguas parece revestir formas mucho más complejas de las que, hasta el momento, se le habían venido suponiendo. Prueba de ello nos lo ofrece, por ejemplo, uno de los epígrafes de Célticos Supertamaricos mencionados con anterioridad: la estela de Crecente o de Apana; en dicho monumento, la onomástica indígena no céltica (los nombres Apana y Apanus) se combina con el reconocimiento de una etnicidad 
céltica (al establecer el origen de la difunta como Céltica Supertamar(i)ca) y con una representación figurada claramente romana (González García, López Barja 2010), dando lugar, así, a una forma híbrida de representar la identidad, forma que también se manifiesta en otras áreas de la Hispania romana, como, por ejemplo, Lusitania (Encarnaçâo 2005: 224 ss.). En segundo lugar, porque, centrándonos en la primera de las anteriores afirmaciones de Calo, no creo que la solución al problema del establecimiento de etnicidades en las sociedades prehistóricas tenga que pasar, necesariamente, por escoger entre cultura material o lengua como criterio básico de determinación. Creo que nadie pondrá en duda la importancia de la lengua y de los datos lingüísticos como marcador étnico $o$, al menos, como mecanismo para la creación de una identidad cultural. Aún así, se trata de un indicador que, para el caso de las sociedades prehistóricas o etnográficas, también resulta problemático como marcador étnico, tal y como lo demuestra el ejemplo del castro de San Cibrán de Las, en el que se atestiguan indicios de tres lenguas distintas: lusitano, céltico y latín (Bernardo Stempel, García Quintela 2008: 269; situaciones similares de coexistencia lingüística en período protohistórico o romano han sido descritas por: Villar 1996: 365; Wells 2001a: 107-109; Wells 2001b: 114-117; Prósper 2004: 181; sobre la existencia de situaciones de este tipo en sociedades orales contemporáneas, Scott 2009: 239-240).

Por fortuna, la arqueología de la Península Ibérica nos ofrece un magnífico ejemplo de las limitaciones de la cultura material como marcador étnico. El yacimiento de Contrebia Belaisca (Botorrita) se adscribiría con total claridad, a juzgar por su cultura material, al mundo íbero sino fuese por el descubrimiento de material epigráfico celtibérico, los famosos bronces de Botorrita, que permitió confirmar que se trataba de un oppidum celtíbérico (Beltrán y Tovar 1982: 40; Fatás 1987: 11). Así es, al menos, como ha entendido e interpretado dicho yacimiento la investigación arqueológica e histórica sobre el mundo celtibérico, seña evidente de que, en otras áreas del territorio español, los condicionantes de la investigación están ideológicamente menos lastrados que en Galicia. El caso de Contrebia Belaisca resulta interesante para la argumentación aquí defendida porque pone de manifiesto los problemas que plantea el uso del material arqueológico como marcador exclusivo de etnicidades. Estos problemas, para el caso concreto de la etnicidad céltica, todavía son más graves, pues, en la actualidad, frente a la monolítica identificación tradicional entre celtas y cultura material de La Tène, se ha venido abriendo paso la idea de que, desde un punto de vista arqueológico, la identidad céltica se debe definir como polimorfa (González García, Parcero Oubiña 2007: 543 ss.).

Esa supuesta homogeneidad de la cultura castreña del NO es una imagen directamente relacionada con el escaso conocimiento o la poca atención que dentro de la investigación protohistórica gallega se ha venido prestando a las diferencias territoriales internas. Tradicionalmente se ha diferenciado entre un sector meridional, el posterior conventus bracarense, caracterizado por castros de mayor tamaño y complejidad y por la presencia de decoración arquitectónica y escultura, y otro sector septentrional, el posterior conventus lucense. Esta diferenciación ha sido aceptada tanto por la investigación arqueológica gallega como por la portuguesa (ver, por ejemplo, Soeiro 1997: 215). Por fortuna, ya contamos, en la actualidad, con síntesis que permiten ver la gran diversidad de tradiciones locales existentes, desde el punto de vista del registro arqueológico, en la Edad del Hierro del NO peninsular (González Ruibal 2006-2007), superando, así, los pocos trabajos que, a este respecto, se habían realizado, con anterioridad, para esta área de estudio (Rey Castiñeira 1993; Carballo, Naveiro y Rey 1988; Carballo 2003).

Pese a ello, sin embargo, ciertos sectores de la investigación histórica y arqueológica han negado la posibilidad de que se pudiese llegar a establecer algún criterio interno de diferenciación dentro del mundo de Edad del Hierro del NO; así parece deducirse de las recientes afirmaciones, ya citadas, de Calo, o de otras afirmaciones que, en este mismo sentido, aseguraban la imposibilidad de "distinguir a los pueblos que, según las fuentes clásicas, pertenecen a la estirpe céltica, frente a aquellos otros que no pertenecen" (Pereira Menaut 1992b: 36). Aseveraciones que, en realidad, son la consecuencia directa de una engañosa uniformidad del registro arqueológico y de la falta de aplicación de estrategias de investigación más refinadas que permitan establecer la existencia de esas diferencias internas.

En realidad, existen diversos indicios que permiten ver que la cultura material del NO durante la Edad del Hierro fue, aún dentro de su uniformidad, 


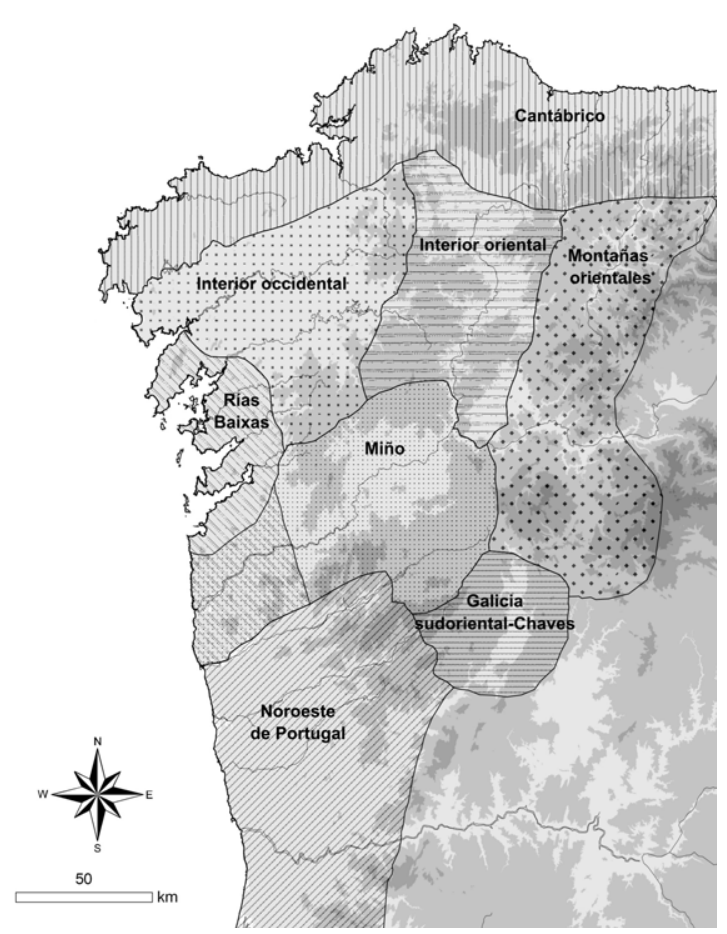

Figura 4.- Decoraciones cerámicas (Fuente: González Ruibal 2006-2007: 467, fig. 4.126).

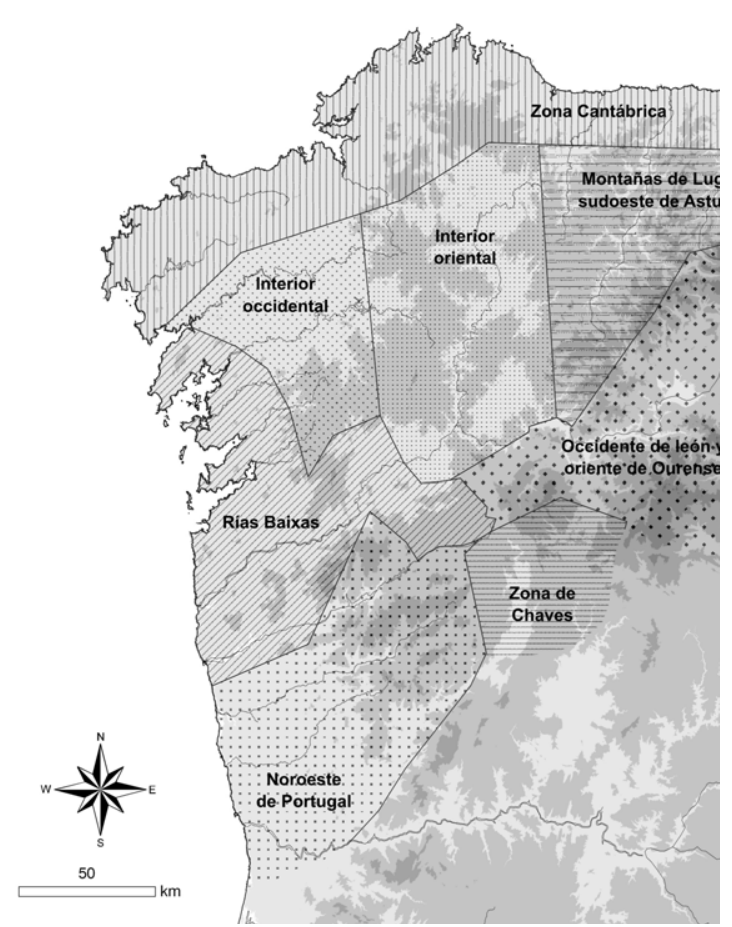

Figura 5.- Técnicas constructivas (Fuente: González Ruibal: 2006-2007: 372, fig. 4.66b). mucho menos homogénea de lo que hasta hace poco se había defendido o que, al menos, dentro de ella se pueden detectar diferencias indicativas de subdivisiones territoriales y, con ellas, de una posible presencia de distintos grupos étnicos dentro de estas regiones (González Ruibal 2006-2007: 450512 ), de tal modo que todos estos grupos habitarían el mismo tipo de asentamiento (el castro) pero muchas de las características externas que los definirían, su cultura material, su lengua, sus dioses, etc., serían distintas.

Para el tema que aquí nos ocupa, los pueblos del litoral mencionados como célticos en las fuentes antiguas, existen indicios que permiten pensar que en esta área se asentó una población caracterizada por una cultura material y un conjunto de creencias que los diferenciaban de algunos de los populi vecinos. Algunos de los mapas de la serie que ilustra las presentes páginas, tomados de dos de los estudios de conjunto realizados sobre diferenciaciones internas dentro de la cultura material de la Edad del Hierro del NO peninsular (Rey Castiñeira 1993: 171; González Ruibal 2006-2007: 372 y 467), permiten diferenciar la existencia, en diversos aspectos materiales, de tradiciones propias en estas áreas del NO.

Tal y como se puede apreciar en el mapa de tradiciones alfareras (Fig. 4), el área del Tambre, zona ocupada por los célticos mencionados por los autores antiguos, se caracterizaría por una forma de hacer propia que abarcaría gran parte de la parroquia altomedieval de Céltigos. Parte de este mismo territorio estaría comprendido dentro de la tradición arquitectónica interior occidental (Fig. 5). La tradición orfebre, en lo que respecta a los torques (Fig. 6), también manifiesta especificidades propias de esta área geográfica, tal y como, por ejemplo, lo ha remarcado, en fecha reciente, el estudio de los torques galaicos realizado por Hautenauve (2005: 115-116 con mapa) al establecer el área de los cursos de los ríos Tambre y Ulla como zonas meridionales de delimitación del grupo 2 de torques galaicos (compuesto por los tipos de torques 3 y 4 que se caracterizan por presentar extremidades piriformes). Dentro de la orfebrería, las arracadas (Fig. 7) también presentan, para esta zona, tradiciones distintas a las de otras áreas del NO, así como diferencias entre el área septentrional del conventus lucense, abarcando la costa, y el sector central del litoral bracarense, con penetraciones hacia el interior. 


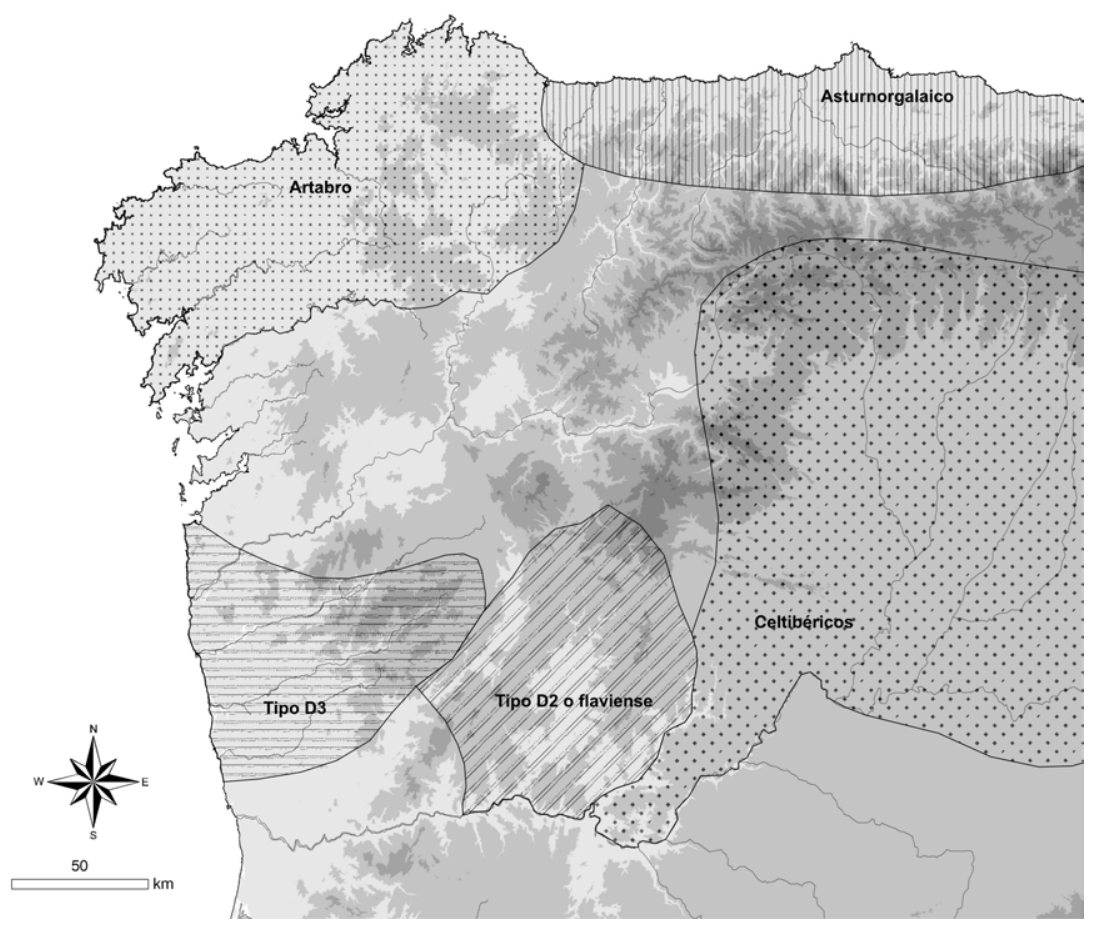

Figura 6.- Torques (Fuente: Rey Castiñeira 1993: 171, mapa 6).

Estos mapas también nos ofrecen la prueba más evidente de la complejidad que presenta la delimitación de grupos étnicos a partir única y exclusivamente de materiales arqueológicos. Como acabamos de ver, la cultura material de los pueblos prerromanos indígenas que habitaban en torno al Tambre se caracteriza, para el caso de la producción alfarera o de las técnicas arquitectónicas, por unas tradiciones propias que los distinguen de sus vecinos. Este hecho no tendría importancia si no fuese porque, por ejemplo, sabemos que el resto de las poblaciones indígenas del $\mathrm{N}$ de la provincia de A Coruña también eran, culturalmente, celtas, tal y como nos informan los autores antiguos, y que en ambas áreas, a juzgar por la pervivencia de abundante toponimia de origen céltico, se habló en época protohistórica una lengua céltica y hubo una intensa ocupación céltica. Estos datos parecen apuntar, por tanto, a que probablemente existieron aspectos de la cultura material que debían de diferenciar internamente a estos grupos célticos. Sin embargo, como podemos apreciar en lo relativo a la producción de orfebrería, parece que todos los pueblos de esta misma área, es decir de la zona del Tambre y del resto del sector septentrional de la provincia de A Coruña, se integran a la perfección dentro de las mismas tradiciones, al menos por lo

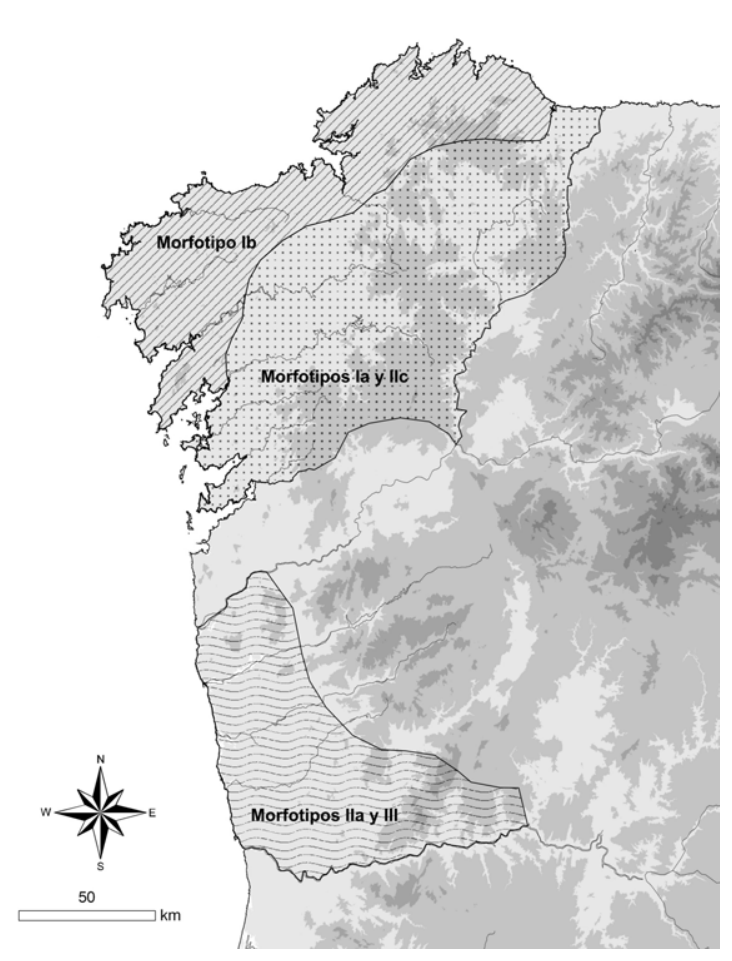

Figura 7.- Arracadas (Fuente: Rey Castiñeira 1993: 171, mapa 7). 


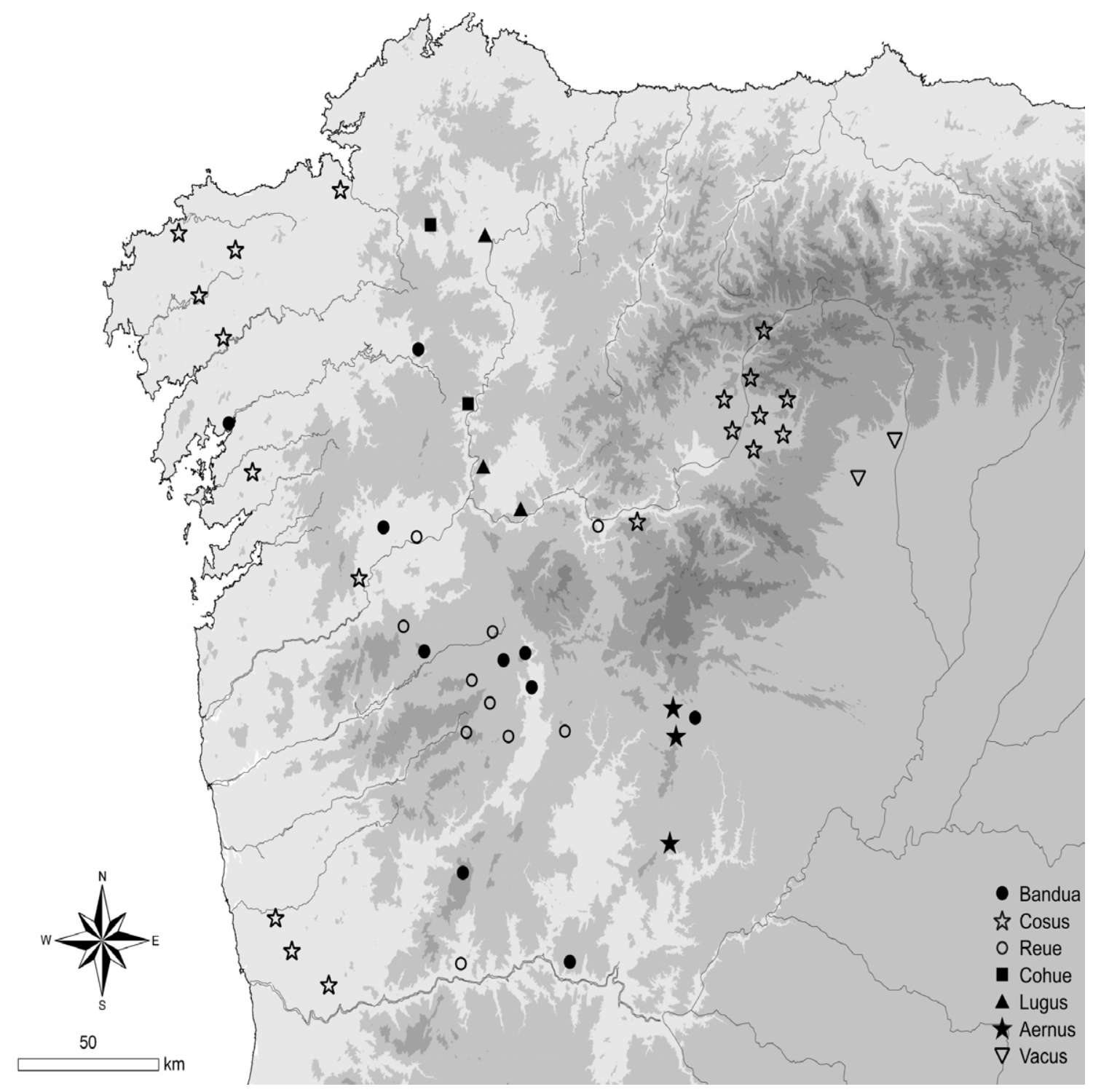

Figura 8.- Divinidades supra-locales de Gallaecia (Fuente: Olivares 2002: 86, mapa 5).

que respecta a los torques, pues en el caso de las arracadas se manifiesta una diferencia más clara entre las zonas de costa e interior de cada una de dichas áreas.

Este no es el único tipo de dato que nos permite caracterizar rasgos propios de las poblaciones que ocuparon durante la Edad del Hierro este sector litoral del NO peninsular. La teonimia documentada en la epigrafía romana hallada en estas áreas costeras también nos permite detectar indicios que apuntan a una caracterización regional de la misma (Fig. 8). Dentro del conjunto de la Península Ibérica, la costa atlántica se caracteriza, como ya había señalado Tranoy (1981: 292) por una acusada presencia de dedicaciones epigráficas a una divinidad supralocal masculina denominada Cosus (Olivares 2002: 158-160). Teónimo que, por otra parte, no cabe duda que se corresponde con una divinidad específicamente galaica (Búa 2003: 157159; Alarcâo 2009: 111-114). La única excepción a esta distribución litoral de la epigrafía de Cosus nos la ofrece la fuerte presencia en sectores de la bracarense y del convento astur, fundamentalmente en el Bierzo, de dedicaciones a dicho dios, si bien con denominaciones distintas (Cossve, Cvsve, Cosei, Cvsei Cosiovi: Olivares 2002: 99 ss,) que 
pueden responder a variantes locales del mismo dios pero bajo nombres ligeramente diferentes (Encarnaçao 1975: 168; para la epigrafía de Cosus: Prósper 2002: 205-224). La existencia de dedicaciones a esta divinidad en el Bierzo se ha interpretado como consecuencia directa de la presencia de indígenas en las unidades militares romanas destacadas en las ricas explotaciones mineras de la zona (García Fernández-Albalat 1990: 260). Prósper (2002: 440), en cambio, ha señalado, basándose en criterios lingüísticos, al territorio astur como área originaria de procedencia de dicha divinidad (críticas a ambas interpretaciones en Búa 2003: 167-171).

Dejando a una lado estas excepciones, cuyo significado, desde un punto de vista étnico, precisaría ser aclarado, lo cierto en que con Cosus prácticamente estamos, de hecho, ante el único dios indígena supralocal atestiguado en el área litoral, pues junto a esta divinidad sólo aparecen teónimos masculinos que nunca exceden el ámbito local (Olivares 2002: 67-68). Se trata de una forma que, en opinión de Prósper, resulta totalmente compatible con una lengua celta $y$, en particular, con el celta de la Península Ibérica; si bien la evolución que dicha autora atestigua para este teónimo la lleva a considerar que se trata de una forma más próxima a las lenguas itálicas que al celta (con respecto a los argumentos en que basa dicha afirmación: Prósper 2002: 244 ss.). Pese a estas objeciones lingüísticas, parece que el culto a Cosus se puede vincular con las poblaciones célticas litorales sobre las que nos hablan los autores antiguos (en este mismo sentido ver: Olivares 2000-2001, $31)$. Este caso, además, viene a poner de manifiesto que la teonimia, tal y como ya había señalado Olivares para el caso de los lusitanos (Olivares 2000-2001) o los vetones (Olivares 2001), es un buen delimitador étnico e identitario (en este sentido ver también Alarcâo 2009: 93-94).

Todo parece indicar, por tanto, que en la zona litoral se documentan una serie de rasgos que la diferencian culturalmente de otras áreas del NO. Parece, así pues, que contamos con una serie de datos, escasos, eso sí, que nos indican que es posible llegar a delimitar, en esta área, subdivisiones internas e, incluso, la presencia de poblaciones cultural y étnicamente distintas.

Los puntos de vista defendidos en las presentes páginas no pretenden, por supuesto, resucitar los viejos presupuestos de la arqueología históricocultural de herencia kossinniana que establece el carácter étnico de una población prehistórica a partir de la constatación de una cultura material idéntica y que atribuye las variaciones en la cultura material a procesos migratorios e invasivos (Trigger 1992, 157 ss.; Fernández Götz 2008: 1945). Mi único interés ha radicado en llamar la atención sobre las coincidencias entre las noticias de las fuentes antiguas y una serie de diferencias internas existentes dentro de esa tan mencionada, por algunos sectores de la investigación, homogeneidad de la cultura material de la Edad del Hierro del NO; coincidencias que, si se investigan, quizás nos puedan ayudar a establecer distintas áreas (culturales, étnicas o políticas) dentro de la protohistoria de dicha región.

En defensa de lo expuesto en las presentes páginas sí deseo señalar, no obstante, que algunos de los criterios aquí indicados (como, por ejemplo, las técnicas, formas y decoraciones cerámicas) con frecuencia se han utilizado, como ha indicado Wells (2001a, 155), para obtener información sobre la identidad étnica de las poblaciones, tanto en estudios etnográficos como históricos o arqueológicos. De hecho, en la arqueología del área indoeuropea de la Península Ibérica contamos con ejemplos de este tipo de aplicación: los intentos realizados para el área vetona por Álvarez Sanchís (2003, 92-98) de llegar a delimitar etnicidades a partir de las diferencias en la decoración cerámica o los trabajos de Burillo (2008: 156 ss.) con relación a los celtíberos. Intentos que están indicando un posible camino hacia una, más que necesaria, reconstrucción de base arqueológica de las etnicidades protohistóricas (Fernández Götz 2008: 119-138).

Existen, por tanto, indicios que parecen apuntar hacia la veracidad de determinadas noticias de las fuentes antiguas sobre el especial carácter cultural y étnico que, dentro de Gallaecia, presentaban los habitantes del litoral, esos grupos humanos a los que los autores griegos y romanos calificaron como keltikoí o celtici. Otro problema distinto es llegar a dotar a esos celtici de utilidad desde el punto de vista histórico, es decir, saber qué era y en qué consistía su celticidad. La respuesta a esta pregunta la ofrecerá, si alguien se decide a retomar dicha cuestión, la investigación en un futuro, pues se trata de un problema terriblemente complejo, dado que enlaza con la cuestión general sobre el origen de los celtas. Cuestión que, evidentemente, se escapa de la finalidad, mucho más modesta, que aquí nos hemos planteado. 


\section{REFERENCIAS BIBLIOGRÁFICAS}

AlarCÂo, J. de (1992): Etnografía da fachada Atlántica ocidental da Península Ibérica. Paleoetnología de la Península Ibérica (M. Almagro Gorbea y G. Ruíz Zapatero, eds.), Complutum, 2-3, Madrid: 229-345.

Alarcâo, J. de (2009): A religiâo de lusitanos e calaicos. Conimbriga, 48: 81-121.

Albertos Firmat, M.L. (1974-1975): Los célticos supertamáricos en la epigrafía. Cuadernos de Estudios Gallegos, 19: 313-318.

Albertos Firmat, M. L. (1990): Los topónimos en -briga en Hispania. Veleia, 7: 131-146.

Alonso Del Real, C. (1977-1978): Estrabón revisitado. Gallaecia, 3-4: 53-69.

Álvarez Sanchís, J.R. (2003): Los señores del ganado. Arqueología de los pueblos prerromanos en el Occidente de Iberia. Akal, Madrid.

AyÁn VILA, X. (2008): A Round Iron Age: The Circular House in the Hillforts of the Northwestern Iberian Peninsula. The celts in the Iberian peninsula (M. Alberro y B. Arnold, eds.): 903-1003. (www4.uwm.edu/celtic/ekeltoi/ volumes/vol6/6_19/ayan_6_19.pdf)

Balbín Chamorro, P. (2006): Hospitalidad y patronato en la Peninsula Ibérica durante la Antigüedad. Junta de Castilla y León, Salamanca.

Beltrán, A.; Tovar, A. (1982): Contrebia Belaisca (Botorrita, Zaragoza). I. El bronce con "alfabeto" ibérico. Universidad de Zaragoza, Zaragoza.

Bermejo Barrera, J.C. (1982): Mitología y mitos de la Hispania Prerromana. Akal, Madrid.

Bermejo Barrera, J.C. (1986): Mitología y mitos de la Hispania Prerromana. II. Akal, Madrid.

Bermejo Barrera, J.C. (2008): Sociedade e relixión na Galicia Antigua. Lóstrego, Santiago de Compostela.

BernaRdo StemPel, P. de (2002): Centro y áreas laterales: la formación del celtibérico sobre el fondo del celta peninsular hispano. Paleohispánica, 2, 89-132.

Bernardo Stempel, P. de; García Quintela, M.V. (2008): Población trilingüe y divinidades del castro de Lansbriga (prov. de Ourense). Madrider Mitteilungen, 49: 254-290.

Berrocal Rangel, L. (1992): Los pueblos célticos del SW de la Peninsula Ibérica. Complutum Extra 2, Madrid.

BRAÑAS, R. (2000): Deuses, heroes e lugares sagrados na cultura castrexa. Sotelo Blanco, Santiago de Compostela.

BTL-1 (1999): Biblioteca Teubneriana Latina. B.G. Teubner-Brepols, Stuttgart \& Leipzig-Turnhout. Ed. en CD-Rom.

Búa CARBAllo, C. (2003): Cosus. Un examplo da epigrafía e relixión. Boletín Auriense, XXXIII: 147-184.

Búa CARBallo, C. (2004): Tres cuestiones relacionadas coa toponimia antiga en -bris, moderna en -bre. Novi ti ex nomine. Estudos filolóxicos ofrecidos ao prof. Dr. Dieter Kremer (Boullón Agrelo, A. I., ed.), Biblioteca Filolóxica Galega Instituto da Lengua Galega - Fundación Pedro Barríe de la Maza, A Coruña: 381-399.

Búa CARBAllo, C.; Lois SiLVA, C. (1994-1995): Los topónimos gallegos en -bre de origen prerromano. Beiträege zur Namenforschung. Neue folge 29-30/1: 13-41.

Burillo Mozota, F. (2008): Los celtíberos. Etnias y estados. Crítica, Barcelona.

Calo Lourido, F. (1993): A Cultura Castrexa. A Nosa Terra, Vigo.

Calo Lourido, F. (2010): Os celtas. Unha (re)visión dende Galicia. Xerais, Vigo.

CARballo ARCEO, L.X. (2003): La Dorsal gallega como barrera intracultural durante la Edad del Hierro. Madrider Mitteilungen, 44: 333-345.

Carballo Arceo, L.X.; Naveiro López, J.L. \& Rey Castiñeira, J. (1988): Problemas de compartimentación espacial do castrexo galaico. Coloquio de Arqueología do Noroeste Peninsular. Actas. Vol. II, Trabalhos de antropología e etnología, 28: 167-183.

Clarke, K. (1999): Between Geography and History. Hellenistic construction of the Roman world. Clarendon Press, Oxford.

Der Neue Pauly (1997): Der Neue Pauly, Encyklopädie der Antike. Altertum. Band 2: Ark-Ci. DTV. StuttgartWeimar.

DuecK, D. (2000): Strabo of Amasya. A Greek man of letters in Augustan Rome. Routledge, Londres.

DueCK, D.; LINDSAY, H.; POTHECARY, S. (eds.) (2005): Strabo's cultural geography: the making of a kolossourgia, Cambridge University Press, Cambridge.

EncarnaçÂo, J. D' (1975): Divinidades indigenas sob o dominio romano en Portugal. Subsidios para o seu estudo. Impresa Nacional-Casa da Moeda Lisboa.

ENCARNAÇÂO, J. D' (2005): Fronteiras lingüísticas, fronteiras intelectuais: o testemunho dos monumentos epigráficos da Lusitânia romana. Fronteiras e etnicidade no mundo antigo. Anais do V Conmgresso da Sociedade Brasileira de Estudos Clásicos, Pelotas: 219-231.

EsTRABÓN (1992): Geografia. Libros III-IV, traducción, introducción y notas de M.J. Meana y F.Piñeiro, Gredos, Madrid.

FATÁs, G. (1987): Apuntes sobre la organización política de los celtíberos. Symposium sobre los celtíberos, Zaragoza: 9-18. 
FernÁndez Götz, M.A. (2008): La construcción arqueológica de la etnicidad. Toxosoutos, Noia.

García Alonso, J.L. (2003): La Península Ibérica en la Geografia de Claudio Ptolomeo. UPV, Vitoria.

García Alonso, J.L. (2006): Briga toponyms in the Iberian Peninsula. The celts in the Iberian peninsula (M. Alberro y B. Arnold, eds.): 689-714. (www.uwm.edu/Dept/celtic/ekeltoi/volumes/vol6/6_15/garcia_alonso_6_15.html).

García Fernández-Albalat, B. (1990): Guerra y religión en la Gallaecia Lusitania antiguas. Castro, Sada-A Coruña.

García Martínez, S.M. (1999): Tres nuevos antropónimos de los Célticos Supertamarcos. Pueblos, lenguas y escrituras en la Hispania Prerromana (F. Villar y F. Beltrán, eds.), Salamanca: 413-420.

García Quintela, M.V. (2009): Sociedad y religión en la Galicia Antigua: una historia del tiempo abolido. Gerión, 27/2: 79-105.

Gómez Espelosín, F.J.; Cruz Andreotti, G.; Garcia Quintela, M.V. (2007): Estrabón: Geografía de Iberia. Traducción de Javier Gómez Espelosín; presentación, notas y comentarios de Gonzalo Cruz Andreotti, Marco V. García Quintela y Javier Gómez Espelosín. Alianza, Madrid.

GonzÁlez García, F.J. (2007): Celtismo e Historiografía en Galicia: en busca de los celtas perdidos. Los pueblos de la Galicia céltica (Francisco Javier González García, ed.), Akal, Madrid: 9-130.

GonZÁlez GARcíA, F.J. (2008): La guerra en la Gallaecia antigua: del guerrero tribal al soldado imperial. Semata, 19: 21-64.

GonzÁlez García, F.J.; LóPez Barja De Quiroga, P. (2010): La estela de Crecente: reflexiones sobre el proceso romanizador en la Galicia antigua. Arqueología, sociedad y territorio. Estudios sobre Prehistoria reciente, Protohistoria y transición al mundo romano en Homenaje a $M^{a}$ Dolores Fernández-Posse (M. Bueno, A. Gilman, C. Martín y F. J. Sánchez Palencia, eds.). Madrid: 349-360.

González García, F.J.; Parcero Oubiña, C. (2007): Bases para el estudio de la etnogénesis galaica. Pasado y presente de los estudios celtas, Ortigueira: 535-562.

GonzÁlez Ruibal, A. (2006-2007): Galaicos. Poder y comunidad en el Noroeste de la Península Ibérica (1200 a.C50 d.C.). Brigantium 18-19, A Coruña.

Gorrochategui, J. (1993): La lengua de los pueblos paleohispánicos. Los celtas: Hispania y Europa (M. AlmagroGorbea, ed.), Universidad Complutense, Madrid: 409-429.

Gorrochategui, J. (1997): Gallaecia e as lenguas prerromanas da Península. Galicia fai dous mil anos. O feito diferencial galego (G. Pereira, Ed.), vol. I, Santiago de Compostela: 15-49.

Hautenauve, H. (2005): Les torques d'or du second Age du Fer em Europe. Techniques, typologies et symbolique. Travaux du Laboratoire de 'Anthropologie, n' 44, Rennes.

Hoz Bravo, J. de (1993): Testimonios lingüísticos relativos al problema céltico en la Península Ibérica.Los celtas: Hispania y Europa (M. Almagro-Gorbea, ed.), Universidad Complutense, Madrid: 357-407.

Hoz Bravo, J. de (1997): Lengua e etnicidade na Galicia antigua. Galicia fai dous mil anos. O feito diferencial galego (G. Pereira, ed.), vol. I, Santiago de Compostela: 101-140.

JordÁ CerdÁ, F. (1984): Notas sobre la cultura castreña del Noroeste peninsular. Memorias de Historia Antigua, VI: 7-14.

López Alsina, F. (1988): La ciudad de Santiago de Compostela en la Alta Edad Media. Ayuntamiento de Santiago, Santiago de Compostela.

Luján, E.R. (2000): Ptolemy's Callaecia and the Language(s) of the Callaeci”. Ptolemy. Towards a linguistic atlas of the earliest Celtic place-names of Europe (D.N. Parsons y P. Sims-Williams, eds.), Aberystwyth: 55-72.

LujÁn, E.R. (2006). The language(s) of the Callaeci. The Celts in the Iberian Peninsula. E-keltoi. Journal of Interdisciplinary Celtic Studies (Arnold, B.; Alberro, M., eds.), Vol. 6: 715-748. (www.uwm.edu/Dept/celtic/ekeltoi).

Moralejo, J.J. (2008): Callaica nomina. Estudios de onomástica gallega. Fundación Barrié de la Maza, A Coruña.

Novo GüIsÁn, J. M. (1997-1998): Lugo en los tiempos oscuros. Las menciones literarias de la ciudad entre los siglos V y X (III). Boletín do Museo Provincial de Lugo, VIII/2: 177-193.

Olivares Pedreño, J.C. (2000-2001): Teónimos y fronteras étnicas: los lusitani. Lucentum, XIX-XX: 5-43.

Olivares Pedreño, J.C. (2001): Teónimos y pueblos indígenas hispanos: los vettones. Iberia, 4: 57-69.

Olivares Pedreño, J.C. (2002): Los dioses de la Hispania céltica. Real Academia de la Historia, Madrid.

Peña, A. de la (2003): Galicia. Prehistoria, castrexo e primeira romanización. A Nosa Terra, Vigo.

Pereira Menaut, G. (1992a): Callaecia. Dialoghi di Archeologia. Terza serie. X/1-2: 319-325.

Pereira Menaut, G. (1992b): Aproximación crítica al estudio de la etnogénesis: la experiencia de Callaecia. Paleoetnología de la Península Ibérica (M. Almagro-Gorbea y G. Ruíz Zapatero, eds.), Complutum, 2-3, Madrid: 35-43.

Pereira Menaut, G. (1998): Los galaicos. Los pueblos prerromanos del Norte de Hispania. Una transición cultural como debate histórico (Rodríguez Neila J.F. y Navarro Santana, F.J., eds.), EUNSA, Pamplona: 301-324. 
Plinio El Viejo (1998): Historia Natural. Libros III-VI. Traducción y notas de A. Fontán, I. García Arribas, E. del Barrio y M.L. Arribas, Gredos, Madrid.

Pomponio Mela (1989): Corografía. Traducción y notas de C. Guzmán Arias, Universidad de Murcia, Murcia.

Prósper, M.B. (2002): Lenguas y religiones prerromanas del Occidente de la Península Ibérica. Universidad de Salamanca, Salamanca.

Prósper, M.B. (2004): Varia Paleohispanica Occidentalia. Paleohispanica, 4: 169-194.

Rey Castiñeira, J. (1993): Cuestiones de tipo territorial en la cultura castreña. Actas del XXII Congreso Nacional de Arqueología, vol. II, Vigo: 165-171.

Rodríguez Colmenero, A. (1999): Sobre dos nuevas estelas monumentales de Lucus Augusti. Pueblos, Lenguas y Escrituras en la Hispania Prerromana (Villar, F. y Beltrán, F., eds.), Salamanca: 605-617.

Rodríguez Corral, J. (2009): A Galicia castrexa. Lóstrego, Santiago de Compostela.

SAStRe PRATS, I. (2001): Las formaciones sociales rurales de la Asturia prerromana. Clásicas, Madrid.

Scotт, J.A. (2009): The art of not being governed. An anarchist history of Upland Southeast Asia. Yale University Press, New Haven-Londres.

Silva, A.C.F. (1983): As tesserae hospitalis do Castro da Senhora da Saúde ou Monte Murado (Pedroso, V. N. Gaia). Contributo para o estudo das instituições e povoamento da Hispânia antiga. Gaia, 1: 9-26.

Silva, A.C.F. (2007): A cultura castreja no noroeste de Portugal. Museu Arqueológico da Citânia de Sanfins Paços de Ferreira ( $2^{\mathrm{a}}$ edición).

SoeIro, T. (1997): O esplendor do Sur da Callaecia. Galicia fai dous mil anos. O feito diferencial galego (G. Pereira, ed.), vol. I, Santiago de Compostela: 213-236.

Tito Livio (1989): Los orígenes de Roma (Libros I-V), edición de M. Pérez González, Akal, Madrid.

Torres Luna, M. P.; Pazo Labrador, A. (1994): Parroquias y arciprestazgos de Galicia. USC, Santiago de Compostela.

Tranoy, A. (1981): La Galice romaine. Recherches sur le nord-ouest de la Péninsule Ibèrique dans l'Antiquité. De Boccard París.

Trigger, B.G. (1992): Historia del pensamiento arqueológico. Crítica, Barcelona.

Untermann, J. (1993): Anotaciones al estudio de las lenguas prerromanas del Noroeste de la Península Ibérica. Galicia: da romanidade a xermanización. Problemas históricos e culturais. Actas do encontro científico en homenaxe a Fermín Bouza Brey, Santiago: 367-397.

Untermann, J. (2004): Célticos y túrdulos. Paleohispanica, 4: 199-214.

Villar, F. (1996): Los indoeuropeos y los orígenes de Europa. Lenguaje e Historia. Gredos, Madrid.

VILlar, F. (2000): Indoeuropeos y no indoeuropeos en la Hispania prerromana. Universidad de Salamanca, Salamanca.

Villar, F. (2001): La lengua de los celtas y otros pueblos indo-europeos de la Península Ibérica. Celtas y Vettones, Ávila: 114-121.

Wells, P.S. (2001a): The barbarians speak. How the conquered peoples shaped Roman Europe. Princeton UP, Princeton \& Oxford.

Wells, P.S. (2001b): Beyond Celts, Germans and Scythians. Archaeology and Identity in Iron Age Europe. Duckworth, Londres. 